\title{
IS CREDIT RATING RESERVED TERRITORY FOR CREDIT RATING AGENCIES? A MULTIMOORA APPROACH FOR EUROPEAN FIRMS AND COUNTRIES
}

\author{
Willem K. M. BRAUERS ${ }^{*}$, Natalija LEPKOVA ${ }^{2}$ \\ ${ }^{1}$ Department of Economics, University of Antwerp, Antwerp, Belgium \\ ${ }^{2}$ Department of Construction Management and Real Estate, \\ Vilnius Gediminas Technical University, Vilnius, Lithuania
}

Received 13 March 2019; accepted 01 June 2019

\begin{abstract}
Credit Rating Agencies rate firms and countries by internal experts but with a final qualitative judgment by their management acting as decision makers. These ratings on their turn influence the countries credit rating and ipso facto of their enterprises. The work of the CRA is in fact double: credit rating of firms and other organizations at one side and countries on the other. Considering the credit rating of firms, the CRA made significant mistakes during the Recession 2007-2009 and their judgment is too much American oriented, in any way from a European point of view. Consequently, in Europe many efforts were made to come to a new agency, but all efforts failed. It could be different for the rating of countries. Is a more scientific approach, eventually on a quantitative and structural basis, not possible? Therefore, MULTIMOORA, a quantitative method, is suggested. The study was made for all countries of the European Continent. Based on data available in 2013 and on their extrapolation, the results are quite comparable to the results of Standard \& Poor's Credit Rating System of the moment. As the classifications of Moody's and Fitch are very similar to those of Standard \& Poor's the outcome would be similar for these other Credit Rating Agencies.
\end{abstract}

Keywords: credit rating agencies, multi-objective optimization, ratio system, reference point method, full multiplicative form, MULTIMOORA.

JEL Classification: C44, E61, F59, M2, O22.

\section{Introduction}

The Multi-objective optimization based on Ratio Analysis Method (MOORA) is one of the known MCDM methods introduced by Brauers and Zavadskas (2006). With the purpose of increasing the robustness of the MOORA method, Brauers and Zavadskas (2010a) added a full multiplicative form to this method and introduced a method called MULTIMOORA as a tool for multi-objective optimization. MULTIMOORA (Multi-objective Optimization on the

*Corresponding author. E-mail: willem.brauers@uantwerpen.be

This is an Open Access article distributed under the terms of the Creative Commons Attribution License (http://creativecommons. org/licenses/by/4.0/), which permits unrestricted use, distribution, and reproduction in any medium, provided the original author and source are credited. 
basis of Ratio Analysis plus full multiplicative form) is a new multi criteria decision-making (MCDM) method which provides high efficiency and effectiveness in problem solving (Dahooie et al., 2019). MULTIMOORA approach has been widely applied in different sectors, such as: industry, economics, civil/environment, medical/healthcare. A. Hafezalkotob, A. Hafezalkotob, Liao, and Herrera (2019) made a deep analysis of MULTIMOORA application. Authors investigated that industries sector has 14 application subsectors including: construction, automotive, agricultural, mining, entertainment, logistics, steel, aviation, beverage, carpentry, energy, ship-building, and textile industries as well as manufacturing system. The most utilized application subsectors from the category of industries are: construction and automotive. Economics sector has 4 application subsectors including: sustainable development, banking system, economic growth, and stock exchange. The most employed application subsector from the category of economics is sustainable development. Civil services \& environmental policy-making sector has two subsectors including: environmental policymaking and bike-sharing program. Medical/Healthcare management sector has 3 application subsectors including: healthcare management, biomedical service, and medical service (Hafezalkotob et al., 2019).

The MULTIMOORA is among the most practical MCDM methods and has been used by many researches to solve complex decision-making problems, including evaluation of healthcare waste treatment technologies ( $\mathrm{Liu}, \mathrm{You}, \mathrm{Lu}, \& \mathrm{Chen}, 2015$ ), selection of biomaterials (A. Hafezalkotob \& A. Hafezalkotob, 2017), selection of residential house construction materials and elements (Zavadskas, Bausys, Juodagalviene \& Garnyte-Sapranaviciene, 2017), evaluation and selection of optimal robot for an industrial application (Zhou, You, Zhao \& Liu, 2018), selection of appropriate performance appraisal method in organizations (Maghsoodi, Abouhamzeh, Khalilzadeh, \& Zavadskas, 2018), selection of the proper technological forecasting method (Dahooie et al., 2019), sustainability assessment for implementation of EU energy policy priorities in the Baltic Sea Region countries (Siksnelyte, Zavadskas, Bausys, \& Streimikiene, 2019) and so forth.

Brauers, Zavadskas, and Lepkova (2017) made a forecast of facilities management sector in Lithuania and for the analysis applied multi-objective optimization method MULMOORA which helped to obtain a ranking of effectiveness of the firms offering facilities management.

Credit rating agencies were analyzed by different authors from different perspectives. Bannier, Hirsch, and Wiemann (2012) investigated whether credit rating agencies affect firm investment decisions. Authors reported that firms reduce (increase) their investment around rating downgrades (upgrades), and interpret this result as being consistent with the monitoring role of credit rating agencies.

Binici and Hutchison (2018) analyzed the problem if the credit rating agencies provide valuable information in market evaluation of sovereign default risk. Luitel, Vanpée, and De Moor (2016) analyzed how the credit rating agencies disadvantage emerging markets. Driss, Massoud, and Roberts (2016) tried to answer the question if credit rating agencies are still relevant? TalhaYalta and YaseminYalta (2018) performed a comprehensive econometric analysis of the credit ratings assigned to 99 countries by Fitch, Moody's and S\&P. The authors evaluated the ratings for eight different country groups plus the U.S. in order to see if the credit rating agencies can be considered to be regionally biased. In addition to regional bi- 
ases, authors also investigate whether there is a "home bias" effect. Park and Lee (2018) using credit rating data from the three credit rating agencies (CRAs) in Korea, examined whether bond issuers and credit rating agencies engage in rating shopping and catering. Marandola (2016) provided a new dataset of credit rating agencies and showed empirical evidence on the determinants of the presence of local agencies and global agencies' branches. Ng and Ariff (2019) tried to answer the question: does credit rating revision affect the price of a special class of common stock? The findings of authors suggest stock prices react significantly to credit change disclosures. Doumpos and Figueira (2019) in their study examined the use of a recently developed multicriteria outranking approach, namely the Electre Tri-nC method, for constructing internal credit rating models in an expert-based judgmental framework. Kim (2019) investigated the role of inflated ratings in peers' investments. The author presented the case of South Korea. Using data pertaining to South Korean firms from 2002 to 2013, the author found that peer firms belonging to industries that have favorable ratings tend to invest more than control firms do, suggesting that a peer effect exists in terms of credit ratings.

The presented article differs from earlier research in the following way. The credit rating agencies were analyzed from different perpective by different authors, but nobody had applied the MULTIMOORA method for comparison and rating.

The article is organized into the following parts. The article begins with introduction section which is providing the literature review. Chapter 1 provides information about credit rating offices and credit rating for firms and for other private and semi-private organizations. Also, the chapter describes choice of objectives characterizing the Economies of the European Countries in the Present and in the Future. Chapter 2 describes Multi-Objective Optimization by Ratio Analysis method (MULTIMOORA). Chapter 3 presents the practical application of MULTIMOORA. Chapter 4 concludes the paper.

\section{The Credit Rating for firms}

\subsection{Some information on Credit Rating offices}

The credit rating business started at the beginning of the 20th century in the United States during the construction of the rail system. The first agencies to provide rating services were Moody's and S\&P that now dominate the market internationally (Marandola, 2016). The three main rating offices: Standard \& Poor's, Moody's and Fitch were founded in the period 1909-1924 (White, 2010; Money Expert, 2011). What can be called, the Big Three represents $96.4 \%$ of the market share (SEC, 2016), meaning that they have a Quasi-Monopoly. The ratings influence the credit rating of the shares and bonds of private companies but also of the government bonds and finally of the countries themselves.

Is it true that Rating Agencies have a lack of transparency and rate countries by unclear methods? More specific for Standard \& Poor's the director for Europe, Mrs. Myriam Fernández de Heredia, affirmed the following (Heredia, 2012): an analyst performs desk research and interviews per country. His conclusions are transmitted to the management, mostly 5 till 7 persons, who determine the rating of a country by simple majority voting. In this way the qualitative judgment of the managers dominates the judgment of the analysts. 
At that moment does the question not arise if a complete quantitative approach is rather superior to this qualitative judgment?

It will become clear from what is following that the approach towards firms or towards countries must be different.

\subsection{The Credit Rating for firms and for other private and semi-private organizations}

Mostly in Europe the Credit Rating Agencies were severely criticized certainly for the mistakes they made during the recession 2007-2009. For instance, the bankruptcy of Lehman Brothers in September 2008 with huge repercussions on the European banking system, was not foreseen. Also, the judgments of the CRA are too much American oriented, in any way from a European point of view. Therefore, some European initiatives were taken.

\subsubsection{ERA of Roland Berger}

Roland Berger is an important consultancy firm of German origin. In the "Corriere della Sera" of January 12, 2012 Berger (2012) launched the idea to set up a: "ERA, European Rating Agency". About 30 institutional investors, banks, insurance companies and stock exchanges would be available to invest in a beginning capital of 300 million $€$. Contacts would be signed at the end of the first quarter of 2012. During the second trimester of 2012 the foundation, an institution without profit making, would come alive. It would be an agency were the clients will pay for an objective and reliable judgment. At the end of 2012 the ratings of countries have to be ready. On this last point, one of the authors of this underlying study, Prof. Brauers, offered his support in a letter of November 13, 2012. Two years after the starting date the entire foundation would be completely operational. Finally, to say with Hamlet: "the rest is silence".

\subsubsection{INCRA of the Bertelsmann Stiftung}

The Bertelsmann Stiftung is a German institution, which in 2012 launched a blueprint for an International Credit Agency, INCRA (Bertelsmann Stiftung, 2012). One of the authors, Prof. Brauers, offered his support during a meeting in 2012 at a German office in Brussels linked to the European Union. Indeed, the Project of Brauers and Zavadskas (2013) on credit rating of countries could be of interest to INCRA, as INCRA had the intention to assign sovereign ratings, with at a further stage also ratings for multi-nationals.

Here also the project was cancelled.

\subsubsection{The European Commission}

It seems that the European Commission has had the intention to install a European Credit Rating Agency. Anyway, as a consequence of the financial crisis 2007-2009, the EU adopted rules on Credit Rating Agencies in three consecutive steps:

1. 2009: a regularity framework for CRA's (Credit Rating Agencies, 2009):

- to be registered and supervised by competent national authorities;

- avoid conflicts of interest; 
- sound rating methodologies;

- transparent rating activities.

2. 2011: creation of ESMA: European Securities and Markets Authority, which supervises the CRA, registered in the EU (ESMA, 2011).

3. 2013: reinforce the rules (Regulating Credit Rating Agencies, 2013).

\subsection{Conclusion about the Credit Rating for firms and for other private and semi-private organizations}

The three main CRA's, Standard\&Poor's, Moody's and Fitch, have a quasi-monopoly in Credit Rating. Standard\&Poor's and Moody's are entirely American and Fitch, said to be for $80 \%$ American, is also entirely under American Influence.

In the US there is quite some regulation on the CRA's but originally not in Europe. European firms complained that they are less protected in that way. One has not to forget that the rating of a firm can have huge consequences on the financing of that firm and often the CRA's change their rates, being profitable for them. There is also a danger of "a selffulfilling-prophesy".

The complaints reached their summit when the CRA's did not foresee the recession of 2007-2009, in particular that they did not foresee the bankruptcy of Lehman Brothers in September 2008, with tremendous influence on the European banks.

At that moment it is understandable that initiatives were taken to come to a European solution, even from the side of the European Commission. Unhappily they failed. Nevertheless, regulations of the European Commission will try to limit the excesses of the CRA's.

From what was said one can conclude that it is nearly impossible to open a new Credit Rating Agency in Europe. The European Union, with its rules to regulate the CRA's, remains the only possibility. In that way one is obliged to recognize the quasi-monopoly of the socalled Big Three (Table 1). At least, it is the case for the corporate bonds ratings counting for $69.8 \%$ of the total revenue of the CRA's with for the big three a market share of $97.02 \%$ (European Commission, 2016).

Table 1. Composition of the Revenue of the Credit Rating Agencies

\begin{tabular}{|l|c|}
\hline Corporate bond ratings & $69.8 \%$ \\
\hline Structured finance products & $18.9 \%$ \\
\hline Sovereign ratings & $11.3 \%$ \\
\hline Total & $100 \%$ \\
\hline
\end{tabular}

However, the credit rating of countries is another story. The research of this study concerns namely what can be done for the estimation of the credit rating of countries. Therefore it has to ask if a more extensive quantitative approach, based on statistics and forecasts, is rather not preferable for the European countries? Such a method has to compare multiple objectives characterizing the economies of each country. 


\subsection{Choice of Objectives characterizing the Economies of the European Countries in the Present and in the Future}

A selection of twenty-two objectives would characterize the European Countries economies as explained in Brauers, A. Baležentis, and T. Baležentis (2012).

The data for these 22 objectives are given in:

1. Concerning the European Union: Brauers and Zavadskas (2013).

2. Concerning the other European Countries: Türe, Kocak, and Dogan (2016). This Turkish publication uses the MULTIMOORA method for Risk Assessment of 78 countries worldwide.

At this moment it is possible to construct a Decision Matrix with the objectives as columns and the European Countries as rows. Such a Decision Matrix will have the form as presented in Table 2 .

Table 2. Decision Matrix Composition

\begin{tabular}{|c|c|c|c|c|c|c|}
\hline & Obj. 1 & Obj. 2 & $\ldots \ldots \ldots$ & Obj. $I$ & & Obj. $N$ \\
\hline Alternative 1 & $x_{11}$ & $x_{21}$ & $\ldots \ldots$ & $x_{i 1}$ & $\ldots \ldots$ & $x_{n 1}$ \\
\hline Alternative 2 & $x_{12}$ & $x_{22}$ & $\ldots \ldots$ & $x_{i 2}$ & $\ldots \ldots$. & $x_{n 2}$ \\
\hline$\ldots \ldots$ & $\ldots \ldots$ & $\ldots \ldots$ & $\ldots \ldots$ & $\ldots \ldots \ldots$ & $\ldots \ldots$. & $\ldots \ldots$ \\
\hline Alternative $J$ & $x_{1 j}$ & $x_{2 j}$ & $\ldots \ldots$ & $x_{i j}$ & $\ldots \ldots$. & $x_{n j}$ \\
\hline$\ldots \ldots$ & $\ldots \ldots$ & $\ldots \ldots$ & $\ldots \ldots$ & $\ldots \ldots \ldots$ & $\ldots \ldots$ & $\ldots \ldots$ \\
\hline Alternative $M$ & $x_{1 m}$ & $x_{2 m}$ & $\ldots \ldots$ & $x_{i m}$ & $\ldots \ldots$ & $x_{n m}$ \\
\hline
\end{tabular}

All the objectives have different denominations. Consequently, there is a question of uniformness, composed of normalization and importance. Therefore, a method has to be chosen to respond to this necessity. It will be treated under next heading.

\section{A Choice of a method for Multi-Objective Optimization}

Already in 1983 at least 96 methods for Multi-Objective Optimization existed (Despontin, Moscarola, \& Spronk, 1983). Since then even much more other methods appeared, either based on weights or on dimensionless measurement.

Preference will be given to the MULTIMOORA method (Brauers \& Zavadskas, 2010a) due to its robustness (Brauers \& Zavadskas, 2010b) and for assembling three methods being all possible methods with dimensionless measures and with the possibility that they control each other.

First, MOORA was developed, composed of two methods: Ratio Analysis and Reference Point Method (Brauers \& Zavadskas, 2006). Later the Full Multiplicative Method was added (Brauers \& Zavadskas, 2010a). 


\subsection{Multi-Objective Optimization by Ratio Analysis (MOORA)}

The two parts of MOORA

The method starts with a matrix of responses of different alternatives on different objectives:

$$
\left(x_{i j}\right) \text {, }
$$

with: $x_{i j}$ as the response of alternative $j$ on objective $i ; i=1,2, \ldots, n$ as the objectives; $j=1$, $2, \ldots, m$ as the alternatives.

MOORA prefer a ratio system in which the response of each alternative on an objective is compared to a denominator, which is representative for all alternatives concerning that objective. For this denominator the square root of the sum of squares of each alternative per objective is chosen. Brauers and Zavadskas (2006) proved that this is the most robust choice:

$$
x_{i j}^{*}=\frac{x_{i j}}{\sqrt{\sum_{j=1}^{m} x_{i j}^{2}}},
$$

with: $x_{i j}=$ response of alternative $j$ on objective $i ; i=1,2, \ldots n ; n$ - the number of objectives; $j=1,2, \ldots, m ; m-$ the number of alternatives; $x_{i j}{ }^{*}=$ a number representing the response of alternative $\mathrm{j}$ on objective $i$.

Once the $x_{i j}{ }^{*}$ from different objectives are compared they become dimensionless numbers. These responses of the alternatives on the objectives belong to the interval $[0 ; 1]$.

An example may clarify this issue. For instance, for the objective "employment" the $x_{i j}{ }^{*}$ of alternative $\mathrm{j}$ is 0.6 and for the objective "value added" e.g. 0.5. When the two numbers are compared they become dimensionless.

Sometimes the interval could even be: $[-1 ; 1]$. Indeed, for instance in the case of productivity growth some sectors, regions or countries may show a decrease instead of an increase in productivity i.e. a negative dimensionless number.

For optimization these responses are added in case of maximization and subtracted in case of minimization:

$$
y_{j}^{*}=\sum_{i=1}^{i=g} x_{i j}^{*}-\sum_{i=g+1}^{i=n} x_{i j}^{*},
$$

with: $i=1,2, \ldots, g$ as the objectives to be maximized; $i=g+1, g+2, \ldots, n$ as the objectives to be minimized; $y_{j}^{*}=$ the assessment of alternative $\mathrm{j}$ with respect to all objectives.

An ordinal ranking in a descending order of the $y_{j}$ shows the final preference.

For the second part of MOORA the Reference Point Theory is chosen with the Min-Max Metric of Tchebycheff (1947) as given by the following formula (Karlin \& Studden, 1966):

$$
\underset{(j)}{\operatorname{Min}}\left\{\max _{(i)}\left|r_{i}-x_{i j}^{*}\right|\right\} \text {. }
$$

\subsection{The importance given to an objective in MOORA}

It may look that one objective cannot be much more important than another one as all their ratios are smaller than one (see formula 1). Nevertheless, it may turn out to be necessary to stress that some objectives are more important than others. To give more importance to an 
objective its ratios could be multiplied with a Significance Coefficient. However, this solution will not change the results (Brauers, 2018). Instead one could use exponents, which is not very advisable because the increase is exponential. It is preferable to introduce sub-objectives, for instance instead of given an importance coefficient of 3 to pollution three kinds of pollution, each with their own criterion, are introduced. Other example: the importance coefficient 2 of employment is compensated by the introduction of sub-objectives: direct and indirect employment.

An interesting comparison of MOORA with other methods is what Chakraborty (2011) has done for industrial management. Chakraborty (2011) checked the most famous methods of multi-objective decision making for decision making in manufacturing with MOORA, showing to be better for: computational time, simplicity, mathematical calculations, stability and information type.

Karuppanna and Sekar (2016) studied the several approaches not only towards manufacturing but also to the service sectors, with the same results.

To the two methods of MOORA a third method is added: the Full Multiplicative Form. The use of three different methods of MOO is more robust than using only two, making MULTIMOORA superior to all existing methods of multiple objectives optimization.

\subsection{MULTIMOORA}

As MOORA is based on dimensionless measures why not going a bit further by adding the remaining form which uses dimensionless measures, namely the Full Multiplicative Form?

The following $n$-power form for multi-objectives is called from now on a Full-Multiplicative Form:

$$
U_{j}=\prod_{i=1}^{n} x_{i j},
$$

with: $j=1,2, \ldots, m ; m$ the number of alternatives; $i=1,2, \ldots, n ; n$ being the number of objectives; $x_{i j}=$ response of alternative $j$ on objective $i ; U_{j}=$ overall utility of alternative $j$.

The overall utilities $\left(U_{j}\right)$, obtained by multiplication of different units of measurement, become dimensionless.

\section{Rule}

In the full-multiplicative form the relation between the utilities $U_{j}$ does not change if more importance is given to an objective by multiplying it by a factor. Indeed, at that moment all alternatives are multiplied with that factor.

\section{Consequence 1}

In the full-multiplicative form the introduction of weights is meaningless. Indeed weights are here in fact multiplying coefficients.

\section{Consequence 2}

In the full-multiplicative form an attribute of the size $10,10^{2}, 10^{3}, 10^{6}, 10^{9}$ etc. can be replaced by the unit size without changing the relationship between the utilities of the alternatives. 
This consequence is extremely important for attributes expressed in monetary units. Instead of expressing an attribute in tens, hundreds, thousands, millions, billions for instance of dollars, the use of one digit in the integer part is enough.

How is it possible to combine a minimization problem with the maximization of the other objectives? Therefore, the objectives to be minimized are denominators in the formula:

$$
\begin{gathered}
U_{j}^{\prime}=\frac{A_{j}}{B_{j}}, \\
\text { with: } A_{j}=\prod_{g=1}^{i} x_{g i},
\end{gathered}
$$

$j=1,2, \ldots, m ; m$ the number of alternatives; $i=$ the number of objectives to be maximized,

$$
\text { with: } B_{j}=\prod_{k=i+1}^{n} x_{k j} \text {, }
$$

$$
n-i=\text { the number of objectives to be minimized, }
$$

with: $U_{j}^{\prime}$ : the utility of alternative $j$ with objectives to be maximized and objectives to be minimized.

In the Full Multiplicative Form a problem may arise for zero and negative values making the results senseless. Therefore, the index number 100 replaces the zero number. At that moment for the same column of the Decision Matrix, for instance 96.6 substitutes the negative value of minus 3.4 and 103.4 represents the positive value of 3.4.

Finally, three different rankings result from MULTIMOORA. How is it possible to come to a most satisfactory ranking? Therefore, Brauers and Zavadskas (2011) developed a Theory of Ordinal Dominance.

\section{Final classification with MULTIMOORA and Ordinal Dominance}

With the assistance of MULTIMOORA and Ordinal Dominance the European Countries are classified after the many objectives cited above.

\subsection{Final classification of the European Countries by MULTIMOORA}

The following Table 3 presents the final classification of MULTIMOORA on basis of Ordinal Dominance Theory. Comparison is made with the Standard \& Poor's rates as being the most important Credit Rating Agency. Detailed calculations are available from the corresponding author on demand. 
Table 3. The final classification of MULTIMOORA for the Economies of the European Countries

A. The CORE-countries

\begin{tabular}{|c|l|c|c|c|c|}
\hline MULTIMOORA & \multicolumn{1}{|c|}{ Countries } & Ratio & Reference point & Multiplicative & S\&P 2018 \\
\hline 1 & Sweden & 2 & 1 & 1 & AAA \\
\hline 2 & Norway & 3 & 8 & 2 & AAA \\
\hline 3 & Switzerland & 4 & 2 & 5 & AAA \\
\hline 4 & Finland & 5 & 5 & 6 & AA+ \\
\hline 5 & Netherlands & 7 & 3 & 8 & AAA \\
\hline 6 & Denmark & 8 & 4 & 10 & AAA \\
\hline 7 & Germany & 9 & 10 & 7 & AAA \\
\hline 8 & Estonia & 6 & 18 & 4 & AA- \\
\hline 9 & Austria & 10 & 6 & 11 & AA+ \\
\hline 10 & Belgium & 14 & 9 & 12 & AA \\
\hline
\end{tabular}

B. The Semi-Core-Countries

\begin{tabular}{|c|l|c|c|c|c|}
\hline 11 & Slovakia & 11 & 13 & 15 & A+ \\
\hline 12 & Lithuania & 12 & 22 & 13 & A \\
\hline 13 & Slovenia & 15 & 12 & 16 & A+ \\
\hline 14 & Czech Rep. & 13 & 14 & 17 & AA+ \\
\hline 15 & France & 18 & 11 & 20 & AA \\
\hline 16 & Hungary & 22 & 19 & 9 & BBB- \\
\hline 17 & Latvia & 17 & 23 & 14 & A+ \\
\hline 18 & Bulgaria & 16 & 24 & 18 & BB- \\
\hline 19 & Malta & 19 & 17 & 19 & A- \\
\hline 20 & Poland & 20 & 21 & 21 & BBB+ \\
\hline
\end{tabular}

C. The Semi-Periphery Countries

\begin{tabular}{|c|l|c|c|c|c|}
\hline 21 & Cyprus & 21 & 27 & 22 & BBB- \\
\hline 22 & U. K. & 23 & 15 & 23 & AA \\
\hline 23 & Italy & 24 & 16 & 24 & BBB \\
\hline 24 & Romania & 25 & 26 & 26 & BBB- \\
\hline 25 & Spain & 26 & 20 & 27 & A- \\
\hline 26 & Ireland & 27 & 28 & 25 & A+ \\
\hline 27 & Portugal & 28 & 29 & 28 & BBB- \\
\hline 28 & Greece & 30 & 30 & 29 & B+ \\
\hline 29 & Croatia & 29 & 31 & 30 & BB+ \\
\hline 30 & Serbia & 31 & 33 & 31 & BB \\
\hline
\end{tabular}

D. The Periphery Countries

\begin{tabular}{|c|l|c|c|c|c|}
\hline 31 & Albania & 33 & 25 & 32 & B+ \\
\hline 32 & Russia & 32 & 32 & 33 & BBB- \\
\hline 33 & Ukraine & 34 & 34 & 34 & B- \\
\hline
\end{tabular}




\subsection{Missing Countries}

- Liechtenstein is a well-known tax-shelter country. It got from S\&P a AAA rating (2018).

- Also, Monaco is a well-known tax-shelter country, but did not receive a Credit Rating from any CRA, perhaps because Monaco has to share its sovereignty with France.

- Andorra got a BBB rating from S\&P (2018).

- Belarus got a B rating from S\&P (2018).

- Bosnia and Herzegovina got a B rating from S\&P (2018).

- Iceland got a A rating from S\&P (2018).

- Moldavia got the following CRs (2018): Moody's: B3; Fitch: B-.

- Montenegro got a B+ rating from S\&P (2018).

- North-Macedonia got a BB- rating from S\&P (2018).

- San Marino got a BBB- rating from Fitch (2018).

- No rating is found for Vatican.

It is a pity that for some European countries sufficient official data are missing in order to make the overview complete.

What is the meaning behind the quotations of Standard \& Poor's? Standard \& Poor's uses the following ratings worldwide (Table 4).

Table 4. The Standard \& Poor's classification

\begin{tabular}{|c|c|}
\hline AAA & Excellent- Maximal Security \\
\hline $\mathrm{AA}+$ & \multirow{3}{*}{ High or Good Quality } \\
\hline $\mathrm{AA}$ & \\
\hline AA- & \\
\hline$A+$ & \multirow{3}{*}{ Average Quality } \\
\hline $\mathrm{A}$ & \\
\hline A- & \\
\hline $\mathrm{BBB}+$ & \multirow{3}{*}{ Less than Average Quality } \\
\hline BBB & \\
\hline BBB- & \\
\hline $\mathrm{BB}+$ & \multirow{3}{*}{ Speculative } \\
\hline BB & \\
\hline BB- & \\
\hline $\mathrm{B}+$ & \multirow{3}{*}{ More than Speculative } \\
\hline $\mathrm{B}$ & \\
\hline B- & \\
\hline $\mathrm{CCC}+$ & Important Risk \\
\hline $\mathrm{CCC}$ & Excessive Speculative \\
\hline CCC- & Nearly Bankruptcy \\
\hline $\mathrm{D}$ & Bankruptcy \\
\hline
\end{tabular}


All European States were assigned to one of the four distinctions of the European system. Core states were the best performing states with ranks from 1 to 10 but with the exclusion of Luxemburg.

\subsection{Luxemburg: another exception}

Luxemburg was originally classified very high in the ranking, despite the fact that it can be classified as a tax shelter country and even more. This position must be reconsidered, otherwise it would be unfair towards the other countries.

- Lux Leaks

The Government admits giving tax benefits and other advantages to profit transferring companies: interview of Michel, Le Monde (2014) with Pierre Gramegna, Minister of Finance of Luxemburg. The minister maintains that Luxemburg has investments under management for 3000 billion Euros, a world leader behind the US. After the minister tax rulings in Luxemburg are no contracts of tax reduction, but a tax evasion system, studying what is allowed after foreign laws and international treaties.

However, The European Commission was so clever to ask information about specific cases like these concerning Fiat and Amazon. The minister was disposed to collaborate for these specific cases but refuses to transmit all existing rulings to the Commission.

The minister concludes "one cannot link a firm to a territory, otherwise it will be suffocated".

- The system of Mailboxes

The address used is only the address of a mailbox, offering the possibility to hide the identity of the receiver and mostly of his financial transactions.

The following typical case can be cited. For the European Football Championship 2000 a stadium was planned in Antwerp South with 30.000 seats for a sum of 3 billion Belgian Francs (of the year 2000). Originally, the investor was a firm "AMFA", officially with a negative capital and no activity for many years (Brauers, 1998). After investigation it was found that the firm had only a mailbox at a small house in a small street in Luxemburg with no further links.

Related to Lux Leaks, Obermayer (2014) of the Süddeutsche Zeitung reported different addresses with more than 1,000 mailboxes, with a maximum of 1600 companies at Rue Guillaume Kroll 5, including Deutsche Bank. A neighbor declared: "the names are changing all the time, but the people inside remains the same".

Contrasting with the mailbox system the huge bank buildings are maintained from the time that millions of middle-class people, carrying non-declared money, arrived by thousands of busses from all over the Benelux, France and Germany. These buildings are kept in the running for prestige, for receiving exceptionally the mailbox people and for installation of a large administrative staff, administering the mailbox operations.

Under these circumstances it is difficult to estimate the economic capability of Luxemburg, certainly with the decline of the steel industry, before the main source of income. Despite the AAA- status after S\&P's, Luxemburg is declassified here given its discussable taxation policy. In this way it is comparable to Liechtenstein, also a well-known tax-shelter country with AAA status. 
Aside its creditability the economic capability of Luxemburg certainly weakened by the decline of the steel industry, before its main source of income. Therefore, the Human Development Index of the United Nations is a good measurement, not including Gross Domestic Product (GDP) with the total production on the territory, but rather Gross National Income of citizens and permanent residents in Purchasing Power Parity per capita (Human Development Report, 2018). After the Report Luxemburg ranks last (21) of the Benelux Countries, after the Netherlands (10) and Belgium (17).

\subsection{European and World classification}

The given classification is only valid in the context of the European system (for the global world-system see for instance: Türe et al., 2016; Clark, 2010). Anyway, in the world-system the ranking between the European countries will not change; but each of them will see its rating change on world level, like an economist ranking $22^{\text {nd }}$ in the EU would rank perhaps $122^{\text {nd }}$ in the world. Indeed, World CORE is different from European CORE (Table 5).

Table 5. Core World level

\begin{tabular}{|c|c|c|c|}
\hline & Türe, Kocak and Dogan & S\&P 2018: AAA & European Countries Classification \\
\hline 1 & Luxemburg & Luxemburg & Sweden \\
\hline 2 & Singapore & Singapore & Norway \\
\hline 3 & Norway & Norway & Finland \\
\hline 4 & Mauritius & Canada & Netherlands \\
\hline 5 & Switzerland & Switzerland & Denmark \\
\hline 6 & Denmark & Denmark & Germany \\
\hline 7 & Netherlands & Netherlands & Estonia \\
\hline 8 & Austria & Germany & Austria \\
\hline 9 & Sweden & Sweden & Belgium \\
\hline 10 & Belgium & Australia & Slovakia \\
\hline 11 & Malta & Liechtenstein & \\
\hline
\end{tabular}

The ranking of Mauritius on world level may look rather strange. It is explainable by becoming a tax shelter country in recent years. Much earlier it could be considered as a sleeping economy (L'Ile Maurice, 1990).

\subsection{Some hot issues}

\subsubsection{Ireland}

In this study Ireland is only classified as a Semi-Periphery Country, still as a function from the fact that Ireland was one of the countries, which suffered the most from Recession 2007-2009. It was accepted that Ireland restored much faster than expected and consequently would take its previous position of an extreme prosperous country. Nevertheless, instead of GDP one has rather to look after National Income or GNP. After recalculations for the 
statistics 2014 one may conclude that national income only represents $62 \%$ of GDP or a difference of 38\%, which is enormous (OECD, Economic Outlook, 2018). The 38\% represents the capital saved by supra-nationals after they contributed to National Income. It becomes disastrous when a foreign government orders that the total capital of the supra-nationals has to be repatriated or that multi-nationals prefer other locations. It happened with the car factories in Belgium. The respective multinationals preferred to re-locate their plants elsewhere. In this way Opel closed its car factory in the Port of Antwerp, Renault its modern, semifactory in Vilvoorde and Ford in the town of Genk. Not only corresponding income was lost but also the subsidies and special facilities offered by the government. Nevertheless, foreign investments remain beneficial for a country as long as if they contribute to national income.

There is even something more, namely Tax Rulings: low taxation for companies practicing profit transfers from higher taxed countries, as was explained for Luxemburg. In August 2016 the European Commission ruled that the Irish Government' light tax treatment towards Apple for an amount of $13 \mathrm{bn} €$ amounted to state aid, illegal under EU rules. It is a sum equivalent to the county's entire healthcare budget or two thirds of its annual social welfare bill (Hodge, 2017).

\subsubsection{United Kingdom}

This study classifies the United Kingdom only as a Semi-Periphery Country corresponding more or less to "less than Average Quality of S\&P's" whereas S\&P's gives "High or Good Quality”. However, for the period 2012-2018 S\&P's changed the UK rate 5 times with still an AAA stable in 2010 (Sovereigns Ratings List, 2018), indicating an unstable position over time. Underlying study is more interested in a structural position with a future-logical outlook under following considerations.

The older generation in the United Kingdom, but mainly in England, still lives in the mentality: "Britannia rules the waves" as before

Table 6. Standard \& Poor's changing its ratings over the period 2012-2018 (Sovereigns Ratings List, 2018)

\begin{tabular}{|l|c|}
\hline \multicolumn{1}{|c|}{ Country } & \\
\hline Russia & 11 \\
\hline Cyprus & 11 \\
\hline Slovenia & 11 \\
\hline Greece & 10 \\
\hline Portugal & 8 \\
\hline Ukraine & 7 \\
\hline Spain & 7 \\
\hline Italy & 7 \\
\hline Ireland & 7 \\
\hline Finland & 6 \\
\hline France & 6 \\
\hline UK & 5 \\
\hline
\end{tabular}
the First World War. However, after that war the United Kingdom lost much of its prestige. The English Pound as world currency was substituted by the American Dollar. After the Second World War it lost all its colonies. One may say that it was the older generation which opted for the "Brexit" with all its uncertainties.

The a-structural characteristics of the Credit Rating can be still best illustrated by the continuous changes in credit rating for different countries, as shown in following Table 6.

It is clear that the rating agencies are changing the rates of the countries too often, whereas the structural situation of the countries does not change so much, here shown for 3-6 years. 
As the classifications of Moody's and Fitch are very similar to these ones of Standard \& Poor's the outcome of the comparison with MULTIMOORA (Table 3) would be the same for those other Credit Rating Agencies.

It has to be noted that the software used is mainly based on Excel. For Excel application see Appendix A.

\subsection{Conclusion concerning the antagonism between this study and the rating agencies regarding the credit rating of countries}

Is it necessary that the CRA changes so often the country ratings with as a result a possible general panic in these countries, together with "a self-fulfilling prophesy"? Also, it could be a mean for the CRA of making itself important or even a mean for profit making. Beside this point of view, it seems necessary to come to a Structural Credit Rating System for countries based on continuity. From now on it will be called: Economic Capability.

For instance, in Belgium, the semi-official organization, CREDENDO, warns the Belgians firms for eventually commercial risk given the political risk on short turn but also on medium term (Credendo, 2019).

However, as the likelihood of occurrence of numerous events is largely uncertain, it is impossible to make predictions over 25 years like Gagnon (2011) has done.

In any case a study on Economic Capability would rely not on "Fingerspitzengefühl", but exclusively on desk research based on:

- official statistics;

- other data which have undergone the test either of complete census or of a sampling with a scientific accepted standard deviation (Brauers, A. Baležentis, \& T. Baležentis, 2018);

- exceptionally in last resort: on simulation. Contrary to many other definitions, simulation is defined in this study in a rather broad sense. Gordon, Enzer, and Rochberg (1970) give the most complete description of simulation as mechanical, metaphorical, game or mathematical analogs. These authors conclude that simulations: "are used where experimentation with an actual system is too costly, is morally impossible, or involves the study of problems which are so complex that analytical solution appears impractical".

\section{Conclusions}

Rating offices rate the solvability of a borrower. Three Rating Agencies of American origin have a quasi-monopoly for credit rating of companies and governments: Standard \& Poor's. Moody's and Fitch. They follow an "Issuer Pays Model". In that case the proverb could play: "bread binds", but if the CRA would follow that proverb it would be the end of their business.

In recent times there was much critique against the CRA's: they did not foresee the bankruptcy of different huge American banks during the recession 2007-2009 and they are suspected of underestimating European companies. Therefore, several initiatives were taken in Europe to set up new CRA's but of European origin and for European firms. They all failed. Only the European Commission adopted rules on Credit Rating Agencies. 
However, the credit rating of countries is another story. Therefore, the research of underlying study concerns what can be done for the estimation of the credit rating of countries, in particular of the European countries.

Instead of qualitative judgment by rating offices, quantitative estimation of the economic rating of the European States by Multi-Objective Optimization is preferred. Therefore 22 objectives were selected to characterize each European State. Next problem was the choice of an effective method of Multi-Objective Optimization. This method has to use complete and not partial aggregation, as an overall view of the countries is needed, and has to avoid the use of weights, this last one being dual on normalization and importance. Therefore methods based on dimensionless measures are preferred. MULTIMOORA responding to all these conditions was finally chosen. In addition MULTIMOORA is composed of three approaches each controlling each other. In this way all possible methods based on dimensionless measures are included.

Having the results of the three approaches, Ratio Analysis System, Reference Point Approach and Full Multiplicative Form, the problem remains how to come to a final and unique solution. Therefore, a Theory of Dominance is proposed. All States were assigned to one of the groups in the European Rating System.

The question can be put if it is necessary that the CRA's change the country ratings all the time with as a result a possible general panic in these countries, together with "a selffulfilling prophesy”. It seems necessary, beside this regular and necessary re-estimation of credit ratings for countries, to come to a Structural Credit Rating System for countries based on continuity. From now on this will be called: Economic Capability.

This kind of study would rely not on "Fingerspitzengefühl" but exclusively on desk research based on:

- official statistics;

- other data which have undergone the test either of complete census or of a sampling with a scientific accepted standard deviation;

- exceptionally in last resort on simulation.

\section{Acknowledgements}

We are very grateful for the hospitality at the Vilnius Gediminas Technical University, now the most important center for research on Multi-Objective Optimization. We have to thank our Turkish colleagues for providing the data for the countries outside Europe.

\section{References}

Bannier, C. E., Hirsch, C. W., \& Wiemann, M. (2012). Do credit ratings affect firm investments? The monitoring role of rating agencies. SSRN, 1-40. https://doi.org/10.2139/ssrn.2135483

Bertelsmann Stiftung. (2012). Blueprint for INCRA, an international non-profit credit rating agency. Retrieved from http://www.bfna.org

Berger, R. (2012, January 12). Corriere della Sera. In De Tijd (Flemish financial newspaper). 
Binici, M., \& Hutchison, M. (2018). Do credit rating agencies provide valuable information in market evaluation of sovereign default Risk? Journal of International Money and Finance, 85, 58-75. https://doi.org/10.1016/j.jimonfin.2018.04.001

Brauers, W. K. M. (1998). Internationaal Voetbalstadion te Antwerpen (Dutch for International Football Stadium in Antwerp). Consulting, Antwerp.

Brauers, W. K. M. (2018). Location theory and multi-criteria decision making:an application of the MOORA method. Contemporary Economics, 12(3), 241-252.

Brauers, W. K. M., Baležentis, A., \& Baležentis, T. (2012). European Union Member States preparing for Europe 2020. An application of the MULTIMOORA method. Technological and Economic Development of Economy, 18(4), 567-587.

Brauers, W. K. M., Baležentis, A., \& Baležentis, T. (2018). Analysis, a possible solution for the standard error in sampling? Journal of Modern Technology \& Engineering, 3(1), 1-14.

Brauers, W. K. M., \& Zavadskas, E. K. (2013). Multi-objective evaluation of the European Union member states. As opposed to Credit Rating Agencies opinions? Transformations in Business \& Economics, 12, 2(29), 102-124.

Brauers, W. K. M., \& Zavadskas, E. K. (2011). MULTIMOORA optimization used to decide on a bank loan to buy property. Technological and Economic Development of Economy, 179(1), 174-188. https://doi.org/10.3846/13928619.2011.560632

Brauers, W. K. M., \& Zavadskas, E. K. (2010a). Project management by MULTIMOORA as an instrument for transition economies. Technological and Economic Development of Economy, 16(1), 5-24. https://doi.org/10.3846/tede.2010.01

Brauers, W. K. M., \& Zavadskas, E. K. (2010b). Robustness in the MULTIMOORA model, the example of Tanzania. Transformations in Business \& Economics, 9, 3(21), 67-83.

Brauers, W. K. M., \& Zavadskas, E. K. (2006). The MOORA method and its application to privatization in a transition economy. Control and Cybernetics, 35(2), 443-469.

Brauers, W. K. M., Zavadskas, E. K., \& Lepkova, N. (2017). The future of facilities management in Lithuania. Romanian Journal of Economic Forecasting, 20(1), 98-115.

Chakraborty, S. (2011). Applications of the MOORA method for decision making in manufacturing environment. International Journal Advanced Manufacturing Technology, 54, 1155-1166. https://doi.org/10.1007/s00170-010-2972-0

Clark, R. (2010). World-system mobility and economic growth 1981-2000. Social Forces, 88(3), 11231151. https://doi.org/10.1353/sof.0.0295

Credit Rating Agencies. (2009). Regulation (Ec)No1060-2009. Retrieved from https://ec.europa.eu/info/ law/credit-rating-agencies-regulation-ec-no-1060-2009

Credendo. (2019, February 12). Retrieved from www.credendo.com; newsletter-eca@credendo.com

Dahooie, J. H., Zavadskas, E. K., Firoozfar, H. R., Vanaki, A. S., Mohammadi, N., \& Brauers, W. K. M. (2019). An improved fuzzy MULTIMOORA approach for multi-criteria decision making based on objective weighting method (CCSD) and its application to technological forecasting method selection. Engineering Applications of Artificial Intelligence, 79, 114-128. https://doi.org/10.1016/j.engappai.2018.12.008

Despontin, M., Moscarola, J., \& Spronk, J. (1983). A user-oriented listing of multiple criteria decision methods. Revue Belge de Statistique, d'Informatique et de Recherche Operationnelle, 23(4), 3-110.

Money Expert. Deutsche Bank. (2011). Retrieved from https://www.deutschebank.be/nl/ratings.html

Doumpos, M., \& Figueira, J. R. (2019). A multicriteria outranking approach for modeling corporate credit ratings: an application of the Electre Tri-nC method. Omega, 82, 166-180.

https://doi.org/10.1016/j.omega.2018.01.003 
Driss, H., Massoud, N., \& Roberts, G. S. (2016). Are credit rating agencies still relevant? Evidence on certification from Moody's credit watches. Journal of Corporate Finance (in press). https://doi.org/10.1016/j.jcorpfin.2016.08.003

European Commission. (2016). Study on the state of the credit rating market (Final report). Retrieved from https://ec.europa.eu/info/system/files/state-of-credit-rating-market-study-01012016_en.pdf

ESMA. (2011). Retrieved from https://www.esma.europa.eu/about-esma

Gagnon, J. E. (2011). The Global Outlook for Government Debt over the next 25 years: implications for the Economy and Public Policy (Vol. 34). Peterson Institute for International Economics, Washington D.C.

Gordon, T. J., Enzer, S., \& Rochberg, R. (1970). An experiment in simulation gaming for social policy studies. Technological Forecasting, 1(3), 241-261. https://doi.org/10.1016/0099-3964(70)90027-X

Hafezalkotob, A., \& Hafezalkotob, A. (2017). Interval MULTIMOORA method with target values of attributes based on interval distance and preference degree: biomaterials selection. Journal of Industrial Engineering International, 13(2), 181-198. https://doi.org/10.1007/s40092-016-0176-4

Hafezalkotob, A., Hafezalkotob, A., Liao, H., \& Herrera, F. (2019). An overview of MULTIMOORA for multi-criteria decision-making: theory, developments, applications, and challenges. Information Fusion, 51, 145-177. https://doi.org/10.1016/j.inffus.2018.12.002

Heredia, F. M. (2012, April 7). De Tijd (Flemish financial news paper, pp. 8-9). Brussels.

Herkenhoff, L., \& Fogli, J. (2013). Applied Statistics for Business and Management using Microsoft Excel. New York: Springer. https://doi.org/10.1007/978-1-4614-8423-3

Hodge, N. (2017, October 24). EC takes on Ireland and Luxembourg over tax avoidance, Compliance Week. Boston. Retrieved from http://www.complianceweek.com/authors/neil-hodge

Human Development Report. (2018). Human Development Indices and Indicators, HDRO. United Nations Development Programme, United Nations.

Karlin, S., \& Studden, W. J. (1966). Tchebycheff systems: with applications in analysis and statistics. New York: Interscience Publishers.

Karuppanna, P. N., \& Sekar, K. (2016). Selection of best alternative in manufacturing and service sector using multigrade decision approach - a review. Computer Science and Information Technology, 57-74.

Kim, H. A. (2019). Are inflated domestic credit ratings relative to global ratings associated with peer firms' investment decisions? Evidence from Korea. Japan and the World Economy, 51, 100956. https://doi.org/10.1016/j.japwor.2019.04.001

L'Ile Maurice. (1990). Nouvelles frontières. Jaguar/Editions, Paris.

Liu, H.-C., You, J.-X., Lu, C., \& Chen, Y.-Z. (2015). Evaluating health-care waste treatment technologies using a hybrid multi-criteria decision making model. Renewable and Sustainable Energy Reviews, 41, 932-942. https://doi.org/10.1016/j.rser.2014.08.061

Luitel, P., Vanpée, R., \& De Moor, L. (2016). Pernicious effects: how the credit rating agencies disadvantage emerging markets. Research in International Business and Finance, 38, 286-298. https://doi.org/10.1016/j.ribaf.2016.04.009

Maghsoodi, A. I., Abouhamzeh, G., Khalilzadeh, M., \& Zavadskas, E. K. (2018). Ranking and selecting the best performance appraisal method using the MULTIMOORA approach integrated Shannon's entropy. Frontiers of Business Research in China, 12(2), 1-21. https://doi.org/10.1186/s11782-017-0022-6

Marandola, G. (2016). InkLocal credit rating agencies: a new dataset. Research in International Business and Finance, 38, 83-103. https://doi.org/10.1016/j.ribaf.2016.03.006

Michel, A. (2014, November 5, 6). Le Luxembourg, plaque tournante de l'évasion fiscale. Le Monde, 5-11. 
Ng, A., \& Ariff, M. (2019, February 22). Does credit rating revision affect the price of a special class of common stock? Borsa Istanbul Review (in press). https://doi.org/10.1016/j.bir.2019.02.004

Obermayer, B. (2014, December 5). Day in fiscal paradise, chasing Letterbox Leads in Luxemburg. Süddeutsche Zeitung.

OECD. (2018). Economic Outlook, 103 database, Stat Link. Retrieved from https://stats.oecd.org/index. aspx?datasetcode $=$ eo $103 \_l t b$

Park, G., \& Lee, H.-Y. (2018). Opportunistic behaviors of credit rating agencies and bond issuers. Pacific-Basin Finance Journal, 47, 39-59. https://doi.org/10.1016/j.pacfin.2017.11.003

Regulating Credit Rating Agencies. (2013). Retrieved from https://ec.europa.eu/info/business-economy-euro/banking-and-finace/financial supervision-and-risk-management/management-riskbanks-and-financial-institutions/regulating-credit-rating-agencies

Quirk, T. (2011). Excel 2010 for business statistics. New York: Springer. https://doi.org/10.1007/978-1-4419-9934-4

SEC, US Securities and Exchange Commission. (2016). Annual Report on nationally recognized statistical organizations, as required by section 6 of the Credit Rating Agency Reform Act of 2006.

Siksnelyte, I., Zavadskas, E. K., Bausys, R., \& Streimikiene, D. (2019). Implementation of EU energy policy priorities in the Baltic Sea Region countries: sustainability assessment based on neutrosophic MULTIMOORA method. Energy Policy, 125, 90-102. https://doi.org/10.1016/j.enpol.2018.10.013

Sovereigns Ratings List. (2018). S\&P, Moody's, Fitch Ratings each for 2018. Retrieved from https:// countryeconomy/com/ratings

TalhaYalta, A., \& YaseminYalta, A. (2018). Are credit rating agencies regionally biased? Economic Systems, 42, 682-694. https://doi.org/10.1016/j.ecosys.2018.08.001

Tchebycheff, P. L. (1947). Complete collected works. Moscow-Leningrad.

Türe, H., Kocak, D., \& Dogan, S. (2016). Country risk assessment with MULTIMOORA method (in Turkish). Gazi Universitesi iktisadi ve idari bilimler fakültesi dergisi, 18(3), 824-844.

White, L. J. (2010). The credit rating agencies. Journal of Economic Perspectives, 24(2), 211-226. https://doi.org/10.1257/jep.24.2.211

Zavadskas, E. K., Bausys, R., Juodagalviene, B., \& Garnyte-Sapranaviciene, I. (2017). Model for residential house element and material selection by neutrosophic MULTIMOORA Method. Engineering Applications of Artificial Intelligence, 64, 315-324. https://doi.org/10.1016/j.engappai.2017.06.020

Zhou, W. Y., You, X. Y., Zhao, H., \& Liu, H. C. (2018). Robot evaluation and selection using the hesitant fuzzy linguistic MULTIMOORA method. Journal of Testing and Evaluation, 47(2), 560-690. https://doi.org/10.1520/JTE20170094

\section{APPENDIX A}

\section{Software for MOORA and MULTIMOORA}

A Table A1 with four sector alternatives and seven objectives is used as didactic material. However, for MOORA and MULTIMOORA there is no limit on the number of objectives and alternative solutions.

Next step consists of a Table A2 for the Same Alternatives and the Same Objectives but this time on Basis of the Formulas. 


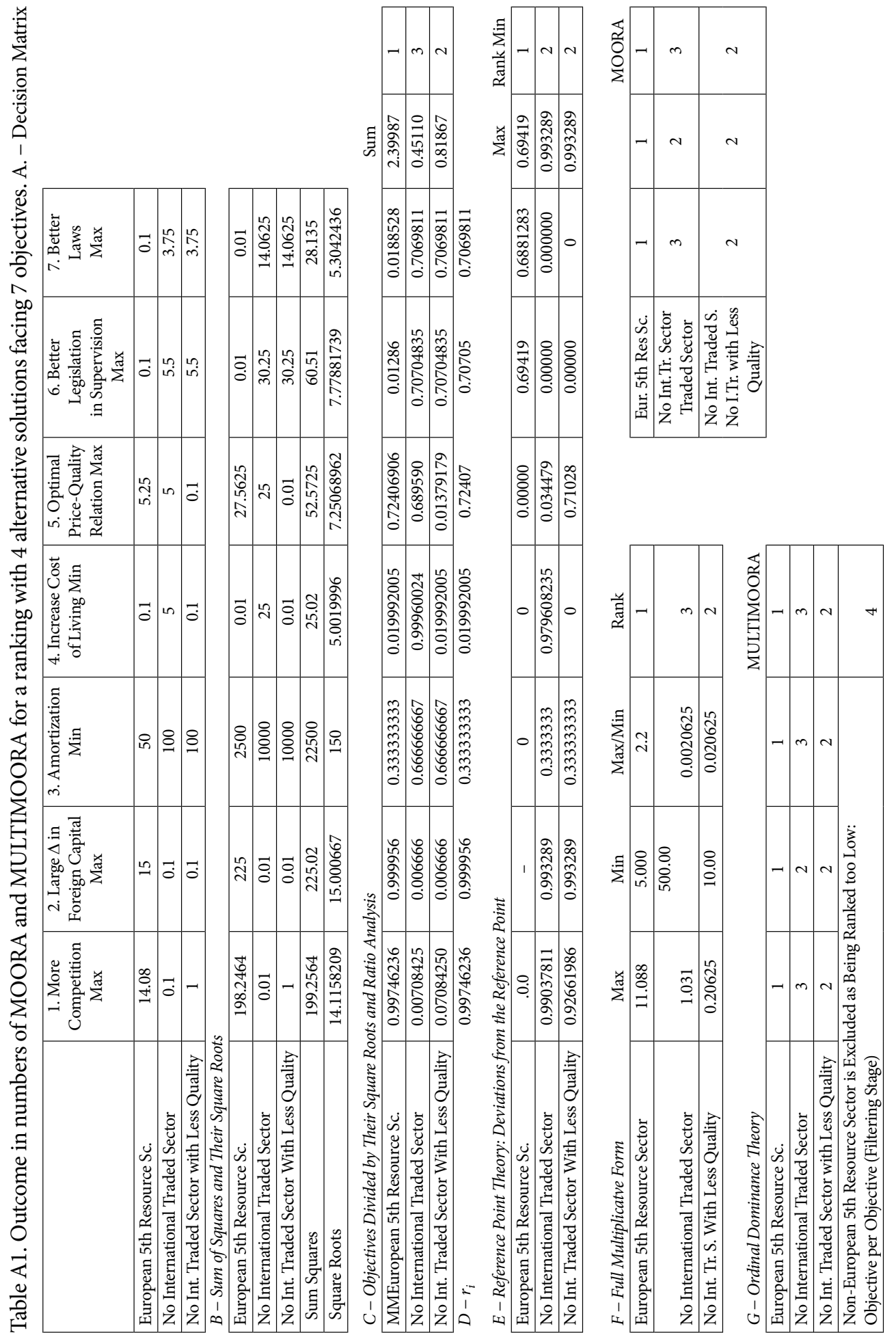




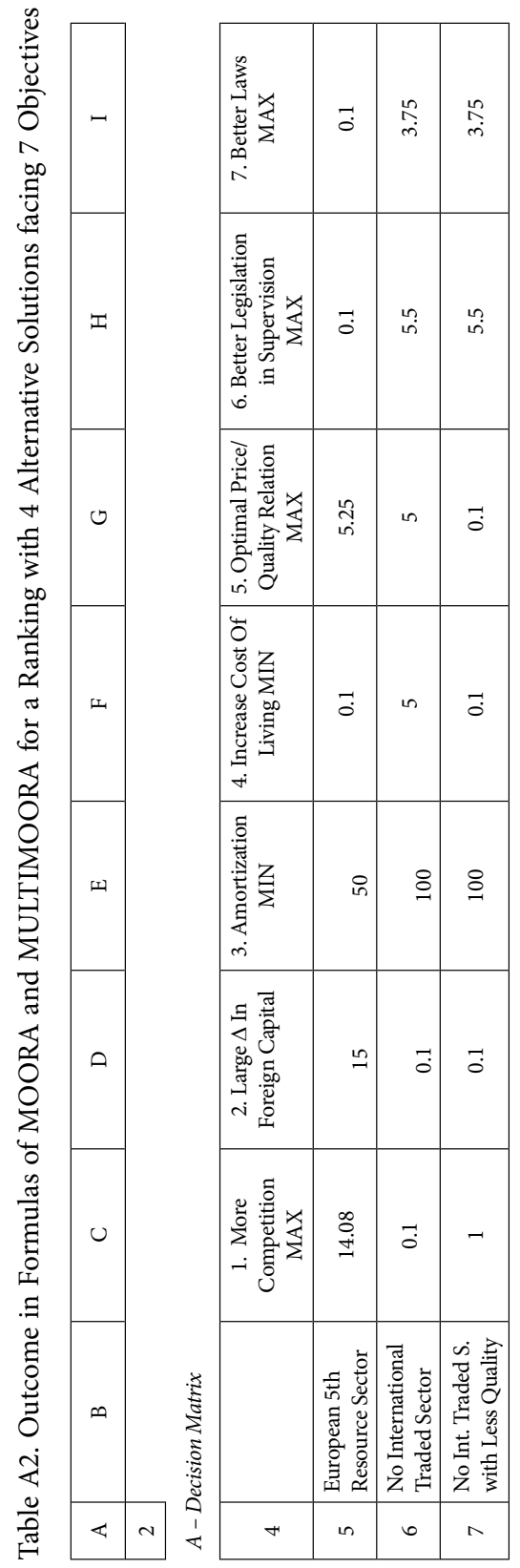

\begin{tabular}{|c|c|c|c|c|c|}
\hline & 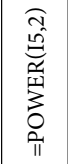 & 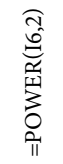 & 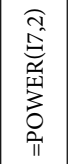 & 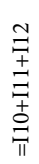 & 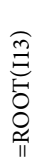 \\
\hline & 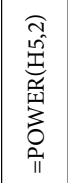 & 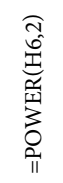 & 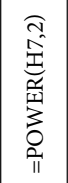 & 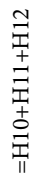 & 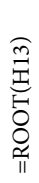 \\
\hline & 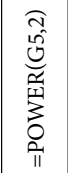 & 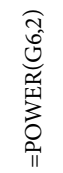 & 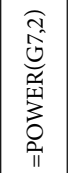 & $\begin{array}{l}\text { U } \\
0 \\
\pm \\
0 \\
0 \\
+ \\
0 \\
0\end{array}$ & 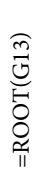 \\
\hline & 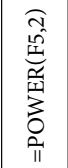 & 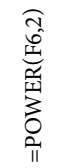 & 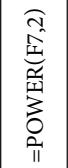 & 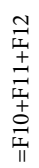 & 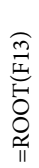 \\
\hline & 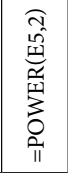 & 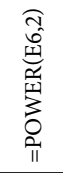 & 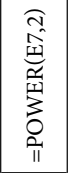 & 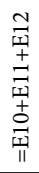 & 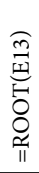 \\
\hline & 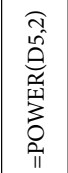 & 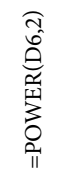 & 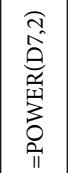 & 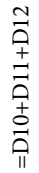 & 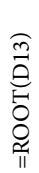 \\
\hline & 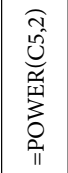 & 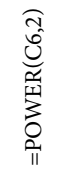 & 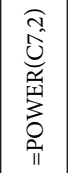 & 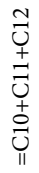 & 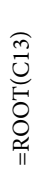 \\
\hline & 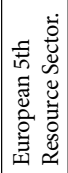 & 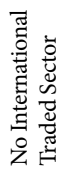 & 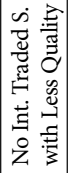 & 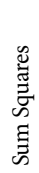 & 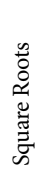 \\
\hline$a$ & ○ & $=$ & $\simeq$ & 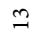 & $\Xi$ \\
\hline
\end{tabular}

$\sum$
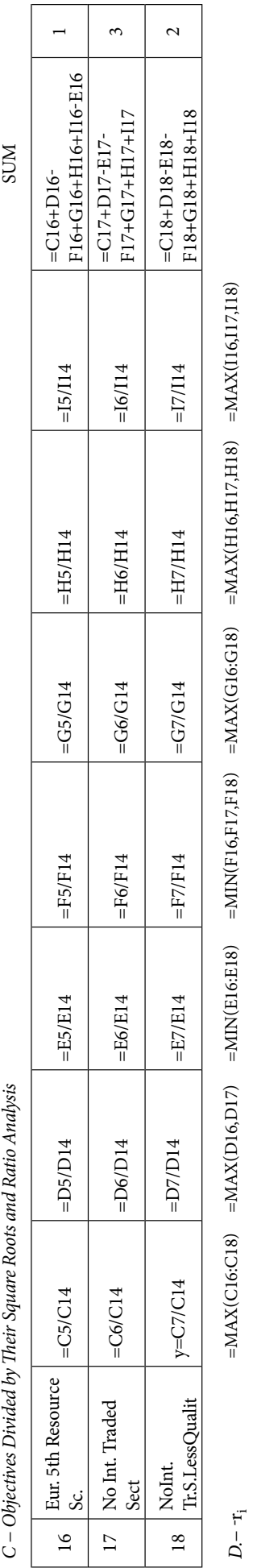


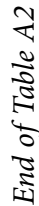

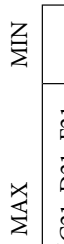

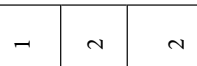

\begin{tabular}{|}
\hline \\
\hline \\
\hline
\end{tabular}

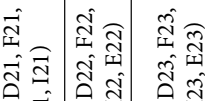

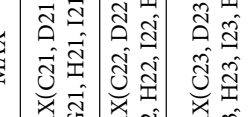
侥

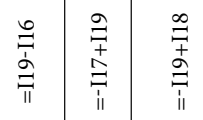

吾

(4

\begin{tabular}{|c|c|c|c|}
\hline 山 & 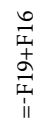 & 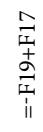 & 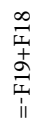 \\
\hline w & 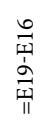 & 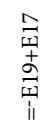 & 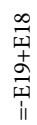 \\
\hline & & ( & 2 \\
\hline
\end{tabular}

学 $-n$ N

\begin{tabular}{l|l|l}
\hline & & \\
0 & 0 & 0 \\
0 & 0 & 0 \\
$\vdots$ & $\vdots$ & $\vdots$ \\
0 & 0 & 0 \\
1. & 11 & $\|$
\end{tabular}

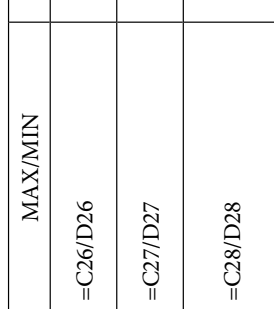

ค

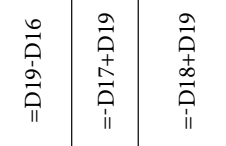
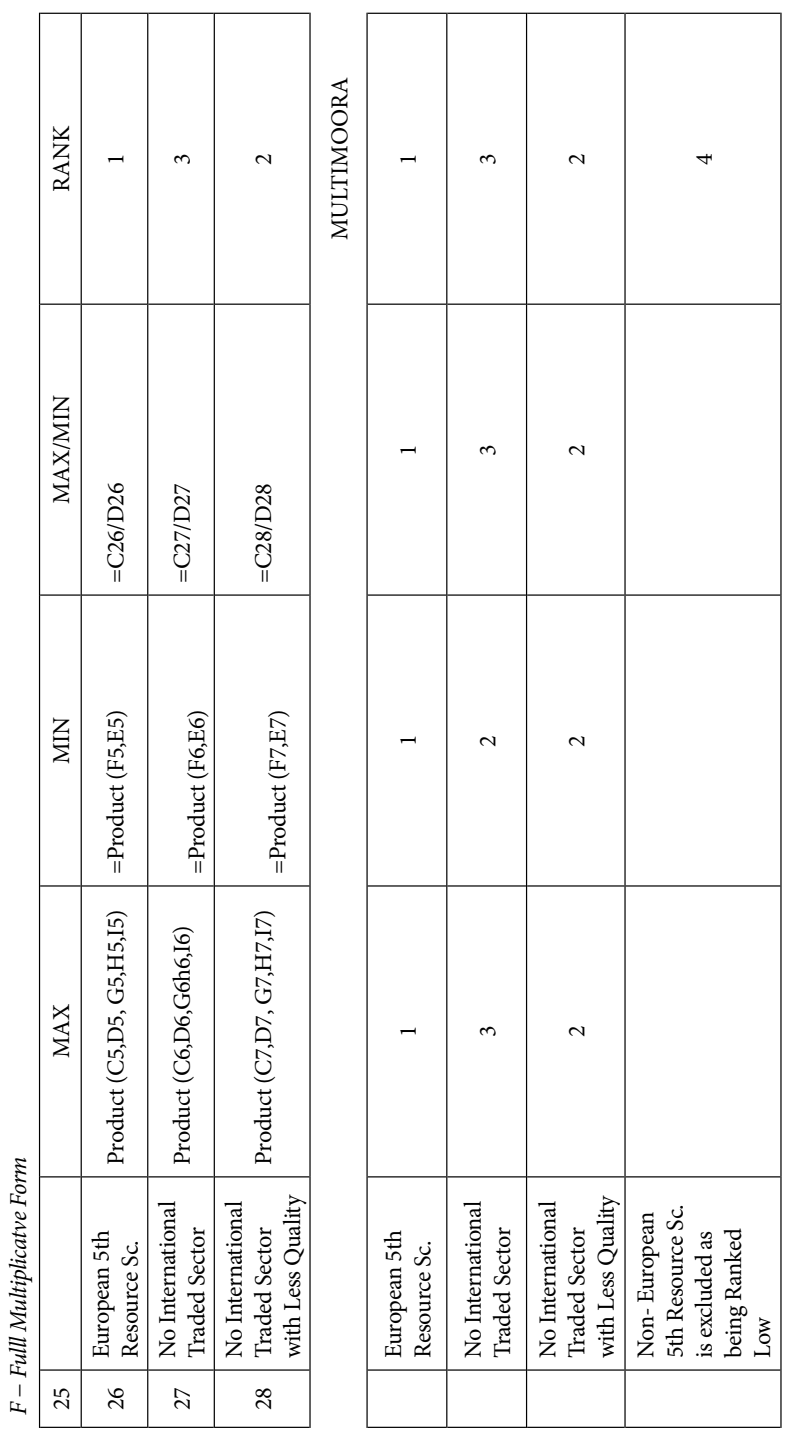


\section{Many applications with EXCEL}

1. Previous tables to be installed in Excel (for Excel see e.g.: Herkenhoff and Fogli, 2013; Quirk, 2011).

2. Once the tables are installed click on "formulas" and then alternatively on "view formulas".

3. Any change in the numbers is possible.

4. Any change in the total of objectives or and of alternative solutions is possible.

5. Introduction of any other decision matrix is possible even with numerous objectives and/or numerous alternative solutions.

\section{Examples:}

1) Brauers, W. K. M., Zavadskas, E. K. (2013). Multi-Objective Evaluation of the European Member States as opposed to Credit Rating Agencies Opinions? Transformations in Business \& Economics, Vol. 12, No. 2 (29): 22 objectives and 27 solutions.

2) Brauers, W. K. M., Baležentis, A., Baležentis, T. (2018). Analysis, a Possible Solution for the Standard Error in Sampling? Journal of Modern Technology \& Engineering Vol. 3, No. 1, pp. 1-14. Baku University, ISSN 2519-4836: 27 objectives and 15 solutions. 